\title{
Paleoecological Significance of Holocene Insect Fossil Assemblages from the North Coast of Alaska
}

\author{
MANDY J. WILSON ${ }^{1}$ and SCOTT A. ELIAS ${ }^{2}$
}

(Received 14 May 1985; accepted in revised form 24 September 1985)

\begin{abstract}
Two peat sections containing insect fossil remains from the eastern coastal plain of the Alaskan North Slope were analyzed in comparison with pollen studies. The sections span a period from 10400 B.P. to 1320 B.P., providing information on the post-glacial distributions of some of the beetles species that were a part of the Beringian refugium fauna. The fossil insect evidence suggests climatic conditions similar to modern parameters, especially in the early Holocene, in general agreement with paleobotanical and vertebrate fossil interpretations for the coastal plain and elsewhere in eastern Beringia.
\end{abstract}

Key words: Holocene, paleoenvironments, insect fossils, Alaska

RÉSUMÉ. Deux sections de tourbe contenant des restes d'insectes fossilisés de la plaine côtière est du nord de l'Alaska furent analysées de façon comparative avec des études polliniques. Les sections dataient d'entre 10400 et 1320 avant notre ère et fournissaient des renseignements sur la distribution post-glaciaire de certaines espèces de coléoptéres qui faisaient partie de la faune du refuge de Béringie. Les restes d'insectes fossilisés suggèrent des conditions climatiques semblables aux paramètres modernes, en particulier durant l'Holocène inférieur, et sont en général conformes aux interprétations des fossiles paléobotaniques et vertébrés pour la plaine côtière et d'autres régions dans l'est de la Béringie.

Mots clés: Holocène, paléoenvironnements, fossiles d'insectes, Alaska

Traduit pour le journal par Maurice Guibord.

\section{INTRODUCTION}

Studies of assemblages of insect fossils have great potential for the reconstruction of Late Quaternary environments, as demonstrated by many recent publications (Coope, 1977; Schwert $e t$ al., 1985; Elias, 1985). In Alaska and the northern Yukon Territory, only three sites of Holocene age have been previously investigated (Matthews, 1975a; Nelson, 1982). To extend knowledge of Holocene climate and ecology in this region, we analyzed assemblages of insect fossils from two peat sections obtained from the northern coastal plain and compared our conclusions with those from pollen analyses from the same sites (Wilson, 1984) and with the conclusions of others.

\section{THE STUDY SITES}

The two analyzed peat sections come from Barter Island $\left(70^{\circ} 8^{\prime} \mathrm{N}, 143^{\circ} 37^{\prime} \mathrm{W}\right)$ and Niguanak Uplands $\left(69^{\circ} 53^{\prime} \mathrm{N}\right.$, $142^{\circ} 45^{\prime} \mathrm{W}$ ) (unofficial name). Both sites are located on the eastern coastal plain of the North Slope of Alaska (Fig. 1).

The Barter Island section comes from the organic deposits that cap the actively eroding coastal bluffs along the north shore of the island to the west of the DEW Line Station. The exposure consists of a large convolution, about $5 \mathrm{~m}$ above present-day sea level, which at some time in the past was probably a horizontal deposit of interbedded sands and organic materials of detrital appearance. The lower part of the convolution was collected. The peat and sand layers were sampled separately. Permafrost, located a few centimeters in from the face of the exposure, limited the sample sizes, which ranged in volume from a few $\mathrm{ml}$ to $200 \mathrm{ml}$. A $90 \mathrm{~cm}$ section was obtained.

Three radiocarbon dates were obtained for the section (Table 1). The date at $0 \mathrm{~cm}$ (the top of the section, not the ground surface) of $7780 \pm 240$ years B.P. is older than the basal date of $6725 \pm 240$ years B.P. The convolution of the section may have caused the deposit to be inverted or it may be that the section is reworked. Hence, the section has been treated as a bulk sample dating from $8000-7000$ years B.P.

The Niguanak Uplands site is situated southeast of Barter Island. The site lies between the Niguanak and Sikrelurak rivers at an elevation of about $61 \mathrm{~m}$. The area has some relief in the form of a series of east-west trending low ridges. Scattered thaw lakes have developed in the area, and the section was taken from sediments exposed by erosion of the east bank of a thaw lake. The vegetation at the top of the section is dominated by species of dwarf willow and included species of drier habitats.

The Niguanak Uplands exposure is composed of a series of peat and sand lenses of varying degrees of oxidation. Again, permafrost located a few centimeters in from the face limited the size of the samples. An $88 \mathrm{~cm}$ section was recovered.

The radiocarbon dates obtained for the section are shown in Table 2. The section spans a period from $10400 \pm 570$ years B.P. to $1320 \pm 160$ years B.P. The date of $8725 \pm 215$ years B.P. is out of sequence with the other dates for the section and may be the result of reworking. For the purpose of the insect fossil analysis the date has been considered as anomalous and disregarded, although its effect on the validity of the section must be considered.

\section{METHODS}

\section{Collection and Preparation of Specimens}

The method used for extraction of insect fossils follows that of Coope (1968). Each sample was wet sieved through a $300 \mathrm{~mm}$ mesh. Samples that did not easily break down were soaked for $24 \mathrm{~h}$ in sodium hexa-meta-phosphate to disaggregate them before sieving. The standard kerosene flotation method for the concentration and extraction of insect fossils from organic detritus was employed. Sorting was carried out under a low-

\footnotetext{
${ }^{1} 18$ Glamis Crescent, Rowlands Gill, Tyne and Wear, United Kingdom NE39 1AT

${ }^{2}$ Institute of Arctic and Alpine Research, Campus Box 450, University of Colorado, Boulder, Colorado 80309, U.S.A.

(C)The Arctic Institute of North America
} 
power stereo binocular microscope. The insect parts were mounted on modified micropaleontology slides with gum tragacanth. Caddisfly larval fossils were mounted in polyvinyl lactophenol medium on glass microscope slides.

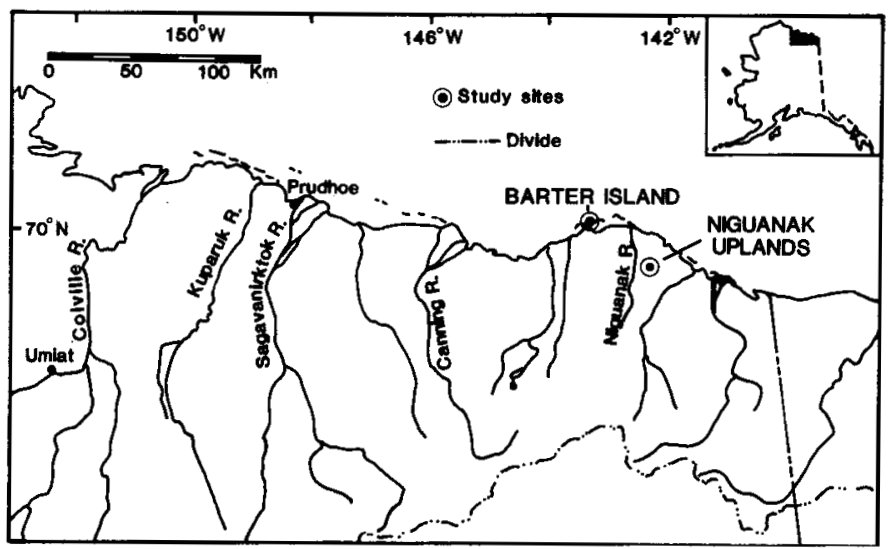

FIG. 1. Location of peat sections.

TABLE 1. Radiocarbon dates for the Barter Island section

\begin{tabular}{cccc}
\hline \hline $\begin{array}{c}\text { Depth } \\
\text { (cm) }\end{array}$ & $\begin{array}{c}\text { Date } \\
\text { (C-14 years B.P.) }\end{array}$ & \multicolumn{1}{c}{ Sediment } & $\begin{array}{c}\text { Geochron } \\
\text { lab. no. }\end{array}$ \\
\hline $0-4$ & $7780 \pm 240$ & Moss detrital peat & GX-9392 \\
$26-27$ & $7870 \pm 310$ & Moss detrital peat & GX-9393 \\
$67-70$ & $6725 \pm 240$ & Sedge peat & GX-9306 \\
\hline \hline
\end{tabular}

TABLE 2. Radiocarbon dates for the Niguanak Uplands section

\begin{tabular}{lclc}
\hline \hline $\begin{array}{l}\text { Depth } \\
\text { (cm) }\end{array}$ & $\begin{array}{c}\text { Date } \\
\text { (C-14 years B.P.) }\end{array}$ & \multicolumn{1}{c}{ Sediment } & $\begin{array}{c}\text { Geochron } \\
\text { lab. no. }\end{array}$ \\
\hline $4-5$ & $1320 \pm 160$ & Sandy peat & GX-9598 \\
$34-35$ & $* 8725 \pm 215$ & Peat & GX-9599 \\
$47-48$ & $3190 \pm 175$ & Peat & GX-9832 \\
$49-50$ & $4330 \pm 225$ & Sandy peat & GX-9600 \\
$87-88$ & $10,400 \pm 570$ & Peat & GX-9394 \\
\hline \hline
\end{tabular}

*Anomalous date.

Identifications of some specimens were by Elias; some specimens were sent to specialists for identification. Taxonomic keys were used in some cases to help identify fossil specimens, but the absence of fragile exoskeletal parts, such as leg and antennal segments, disallows the use of such keys for most specific identifications. Specific determinations were made on the basis of comparisons between fossil parts and modern, identified specimens. When the only available fossil sclerites from a given taxon were lacking in sufficient diagnostic characters to allow specific identification, these fossils were determined to the generic or family level. Whenever possible, the fossils were compared with large series of modern specimens, in order to maximize the certainty of the fossil identifications. The level of intraspecific variation of beetle exoskeletal morphology appears to be greater in high latitude species than elsewhere; structural differences are especially common between northern and southern populations and across the east-west ranges of populations (Danks, 1981).

\section{Interpretations of Data}

The use of insect fossil evidence in the reconstruction of past environments specifically for the Quaternary period has been facilitated during recent years by the realization that there has been no significant morphological evolution of the Coleoptera during the Quaternary. Prior to the fossil insect investigations of Lindroth (1948) and Coope (1959 onwards) and associates, many entomologists had been quick to describe beetle fossils as extinct species (e.g., Lomnicki, 1894; Mjöberg, 1916). Recent studies of these (Angus, 1973; Lindroth, 1948) and other assemblages supposed to contain extinct beetle species have proven otherwise, in that the specimens in question were shown to belong to extant species. This view of the stability of Coleoptera species during the Quaternary has been amply supported by the fossil evidence from scores of Quaternary insect assemblages examined recently. This evidence strongly suggests that there has been no appreciable morphological evolution in Coleoptera for at least the last million years. The most recent beetle fossils indicating variation of characters beyond the accepted range of variation for the modern species are found in late Tertiary deposits (Matthews, 1974, 1976). The constancy of beetle species has been more fully discussed by Coope (1978).

A necessary assumption that must be made if Quaternary insects are to be used as paleoenvironmental indicators is the stability of their ecological requirements during this period. This is an assumption common to all biological interpretations of past environments. Unlike external morphology, we have no way of directly observing any physiological changes in the fossil record. One may infer a great deal, however, from the constancy of associations of species, especially when the same suites of species associated in the past are found still living together in the modern environment. In European and North American fossil studies, suites of beetle species from numerous genera and families are repeatedly found associated together. Examinations of their modern ecological requirements and geographic ranges most often reveal a continuity of ecological and zoogeographic relationships and associations. One may argue that a given species has undergone physiological evolution between the time of fossil deposition and the present, and thus its ecological requirements have changed. But the probability is very small that a whole association of beetles found together in a fossil assemblage had undergone an exactly similar degree of physiological evolution such as would allow them to have collectively compatible, though different, ecological requirements in the past compared with the present (Elias and Wilkinson, 1983).

\section{MODERN HABITATS AND DISTRIBUTION OF FOSSIL FAUNA}

\section{Barter Island}

Table 3 presents a list of insect fossils recovered from the Barter Island site and their known ecological requirements. Only 102 insect and arachnid individuals (based on the minimum number of individuals) were recovered from the entire section. This low number reflects the small quantity of original sample and the low concentration of insect fossils in the samples. The 102 individuals represent 40 taxonomic groups (including specimens identified only to family level). Eleven of these taxa were identified to genus level; 15 species were identified. Of these individuals $85 \%$ were Coleoptera (beetles), $1 \%$ Hymenoptera (wasps), 6\% Trichoptera (caddisflies) and 9\% class Arachnida, order Acarina (mites). Numerous ephippia (egg cases) of the crustacean Daphnia were also found in the samples; 
TABLE 3. Annotated list of insect species recovered from the Barter Island section, showing minimum number of individuals and habitat preferences

\begin{tabular}{|c|c|c|}
\hline Taxon & Minimum number of individuals & Habitat preference \\
\hline \multicolumn{3}{|l|}{ Class: INSECTA } \\
\hline \multirow{2}{*}{\multicolumn{3}{|c|}{$\begin{array}{l}\text { Order: COLEOPTERA } \\
\text { Family: Carabidae }\end{array}$}} \\
\hline \multirow{2}{*}{\multicolumn{2}{|c|}{$\begin{array}{l}\text { Family: Carabidae } \\
\text { Notiophilus borealis Harris }\end{array}$}} & \\
\hline & 1 & $\mathrm{X}, \mathrm{O}, \mathrm{B}-\mathrm{Arc}$ \\
\hline Bembidion sp. & 2 & $\mathbf{M}$ \\
\hline Pterostichus (Cryobius) cf. nivalis F. Sahlb. & 1 & $\mathbf{X}, \mathbf{T}$ \\
\hline Pterostichus sp. & 1 & $\mathbf{M}$ \\
\hline Cymindis cf. unicolor Kby. & 1 & $X,(T)$ \\
\hline Genus indet. & 7 & \\
\hline \multicolumn{3}{|l|}{ Family: Dytiscidae } \\
\hline Hydroporus cf. fuscipennis Schaum & 1 & $\mathrm{~A}, \mathrm{C}$ \\
\hline Hydroporus morio Aube. & 2 & A,SP,B \\
\hline Hydroporus cf. notabilis Leconte & 1 & $A, B$, Arc \\
\hline Hydroporus cf. notabilis Leconte or arcticus Thoms. complex & 1 & A \\
\hline Agabus cf. inscriptus Crotch & 1 & A,SP \\
\hline Agabus sp. & 3 & $\mathbf{A}$ \\
\hline Ilybius angustior Gyll. & 1 & A,EmV \\
\hline Genus indet. & 3 & $\mathbf{A}$ \\
\hline \multicolumn{3}{|l|}{ Family Gyrinidae } \\
\hline Genus indet. & 1 & $\mathbf{A}$ \\
\hline \multicolumn{3}{|l|}{ Family Hydrophilidae } \\
\hline Helophorus cf. parasplendidus Ang. & 1 & $\mathrm{~A}, \mathrm{EmV}, \mathrm{Arc}$ \\
\hline Enochrus sp. & 1 & \\
\hline Genus indet. & 1 & A \\
\hline \multicolumn{3}{|l|}{ Family Hydraenidae } \\
\hline Genus indet. & 1 & A \\
\hline \multicolumn{3}{|l|}{ Family Staphylinidae } \\
\hline Eucnecosum sp. & 3 & $\mathbf{M}, \mathbf{L}$ \\
\hline Olophrum sp. & 3 & \\
\hline Holoboreaphilus nordenskioeldi (Makl.) & 7 & $\mathrm{M}, \mathrm{Arc}, \mathrm{L}$ \\
\hline Omaliinae indet. & 10 & \\
\hline Micralymma brevilingue Schiödt & 1 & $\mathbf{X}, \mathbf{A r c}$ \\
\hline Stenus hyperboreus J. Sahlb. & 3 & M,B-Arc,C,EmV \\
\hline Stenus kamtschaticus Mots. & 1 & $\mathrm{M}, \mathrm{Arc}, \mathrm{C}, \mathrm{EmV}$ \\
\hline Stenus sibiricus J. Sahlb. & 1 & $\mathrm{M}, \mathrm{T}, \mathrm{L}$ \\
\hline Stenus sp. & 6 & $\mathbf{M}$ \\
\hline Lathrobium sp. & 2 & \\
\hline $\begin{array}{l}\text { Quedius sp. } \\
\text { Aleocharinae indet. }\end{array}$ & 1 & $\mathbf{M}$ \\
\hline Genus indet. & 5 & \\
\hline \multicolumn{3}{|l|}{ Family: Leiodidae } \\
\hline Genus indet. & 1 & $\mathbf{A}$ \\
\hline \multicolumn{3}{|l|}{ Family: Elateridae } \\
\hline Genus indet. & 1 & $\mathbf{M}$ \\
\hline \multicolumn{3}{|l|}{ Family: Chrysomelidae } \\
\hline Pyrrhalta sp. & 2 & $\mathbf{A}$ \\
\hline \multicolumn{3}{|l|}{ Family: Curculionidae } \\
\hline cf. Dorytomus sp. & 4 & $\mathbf{M}, \mathbf{S}$ \\
\hline \multirow{2}{*}{\multicolumn{3}{|c|}{$\begin{array}{l}\text { Genus indet. } \\
\text { Order: HYMENOPTERA } \\
\text { Family: Belytidae }\end{array}$}} \\
\hline & & \\
\hline \multicolumn{3}{|l|}{ Family: Belytidae } \\
\hline Belyta sp. & 1 & \\
\hline \\
\hline Family: Limnephilidae & & \\
\hline \multirow{2}{*}{\multicolumn{3}{|c|}{$\begin{array}{l}\text { Genus indet. (Larvae) } \\
\text { Class: ARACHNIDA }\end{array}$}} \\
\hline & & \\
\hline \multicolumn{3}{|l|}{$\begin{array}{l}\text { Order: ACARI } \\
\text { Family: Oribatidae }\end{array}$} \\
\hline Family: Oribatidae & & \\
\hline Genus indet. & 9 & $\mathbf{M}$ \\
\hline Class: CRUSTACEA & & \\
\hline Order: CLADOCERA & & \\
\hline Daphnia sp. & Abundant & $\mathbf{A}$ \\
\hline
\end{tabular}

Key

A

Arc

Aquatic environment

$\mathrm{EmV}$

Boreal forest region

B-Arc Boreal-Arctic distribution

C Carex marshes, shallow water

$\begin{array}{ll}\text { L } & \text { Leaf litter } \\ \text { M } & \text { Mesic environment }\end{array}$

O Open ground
S Associated with Salix

SP Small vegetation ringed pools

T Only on tundra

(T) Predominantly on tundra but not obligatory

$X$ Xeric environment 
these have been excluded from the calculation of the minimum number of individuals.

Figure 2A illustrates the percentage of individuals known to prefer aquatic, mesic and xeric habitats respectively. Twentyeight percent of the individuals are associated with aquatic habitats, $39 \%$ with mesic habitats and $4 \%$ with xeric habitats. Twenty-nine percent of the individuals could not be classified into one of the three substrate moisture preference categories because of lack of specific identifications.
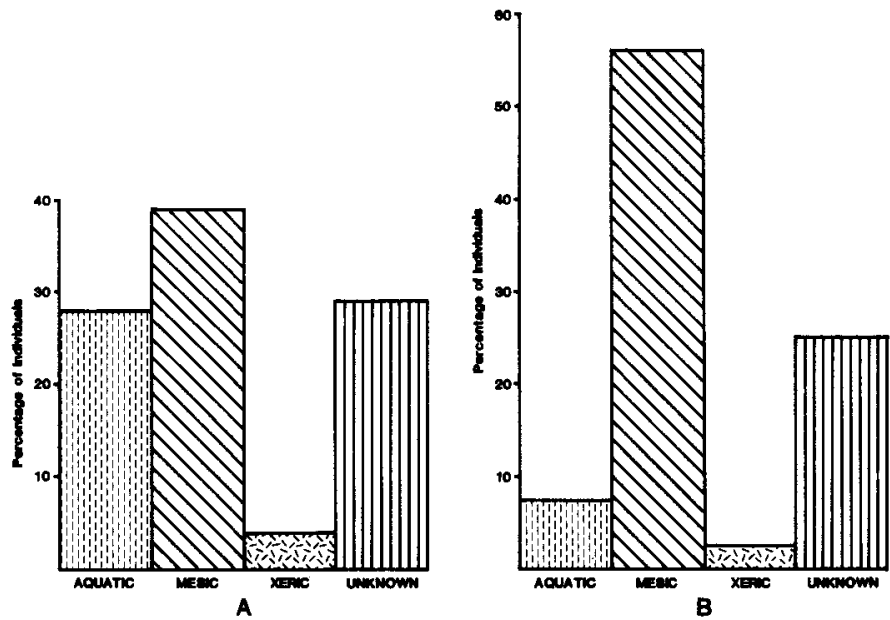

FIG. 2. Habitat moisture preferences of fossil insects recovered from (A) the Barter Island section and (B) the Niguanak Uplands section.

All the genera identified are characteristic of northern tundra environments today. Most species of Bembidion are commonly associated with stream or lake margins; Pterostichus (Cryobius) species are for the most part associated with mesic tundra habitats where the vegetation is moderately continuous, consisting, at least in part, of graminoid species but often including low shrub species such as Betula nana and Ledum palustre (Nelson, 1982). Matthews (pers. comm. 1983) notes that one of the Cryobius fossil pronota (Fig. 3B) is a good match for $P$. (Cryobius) nivalis, a species characteristic of well-drained sandy substrates with a discontinuous vegetation cover (Ball, 1966; Lindroth, 1966). Pterostichus nivalis has a modern distribution corresponding to the Beringian regions of eastern Siberia and Alaska (Fig. 4A). Eucnecosum, Olophrum, Stenus and Quedius are other examples of genera that prefer damp or riparian areas. Stenus hyperboreus (Fig. 3H) and Stenus kamtschaticus (Fig. 3I) are both common at high latitudes in North America today, living mainly near ponds in Carex swamps and humid meadows or in Sphagnum. Both species have a holarctic distribution, although $S$. kamtschaticus is more restricted (Fig. 4D), recorded in Alaska only from Unalakleet, Mile 1249 of the Alaska Highway (Deadman Lake), and at Bonanza Creek $\left(150^{\circ} 40^{\prime} \mathrm{W}, 66^{\circ} 40^{\prime} \mathrm{N}\right)$ on the Dalton Highway (Puthz, pers. comm. 1983). Stenus sibiricus (Fig. 3J) also has a wide holarctic range and is found on the open tundra, in Vaccinium, lichen, moss and Populus litter. Puthz (pers. comm. 1983) notes that two different forms of the species exist. $\mathrm{He}$ identifies the Barter Island fossil as belonging to $S$. sibiricus $A$, as he designates it. Holoboreaphilus nordenskioeldi (Fig. 3G) is known from northern Siberia and arctic localities in North America. It appears to be associated with damp habitats. Campbell (1978) notes that adults have been collected by sifting arctic willow litter near streams, by sifting moss and grass near a small wet area and by treading grass clumps growing in shallow water; it occurs in both tundra and in the forest-tundra ecotone.

Where it is possible to assign specific ecological requirements, most of the aquatic beetles are found in standing or slow flowing water. Most species of Agabus live in shallow water along the margins of small pools where the emergent vegetation or detritus is very dense (Larson, 1975). Larson has tentatively identified one of the Agabus fossils as A. inscriptus, a species characteristic of small, vegetation-ringed pools.

Hydroporus fuscipennis is holartic in distribution and has been recorded from the Northwest Territories and the Yukon Territory (Larson, 1975). Larson records it from shallow water and Carex marshes in Alberta. Hydroporus morio (Fig. 3F) has a circumpolar distribution and has been found in small, cold woodland pools usually in or near coniferous forests, again in Alberta (Larson, 1975). Hydroporus notabilis is a species of more southern distribution. However, Larson (1975) notes that Fall (1923) and other subsequent authors have suggested that the species $H$. arcticus includes small northern adults of $H$. notabilis. It is likely that the specimen recorded in the Barter

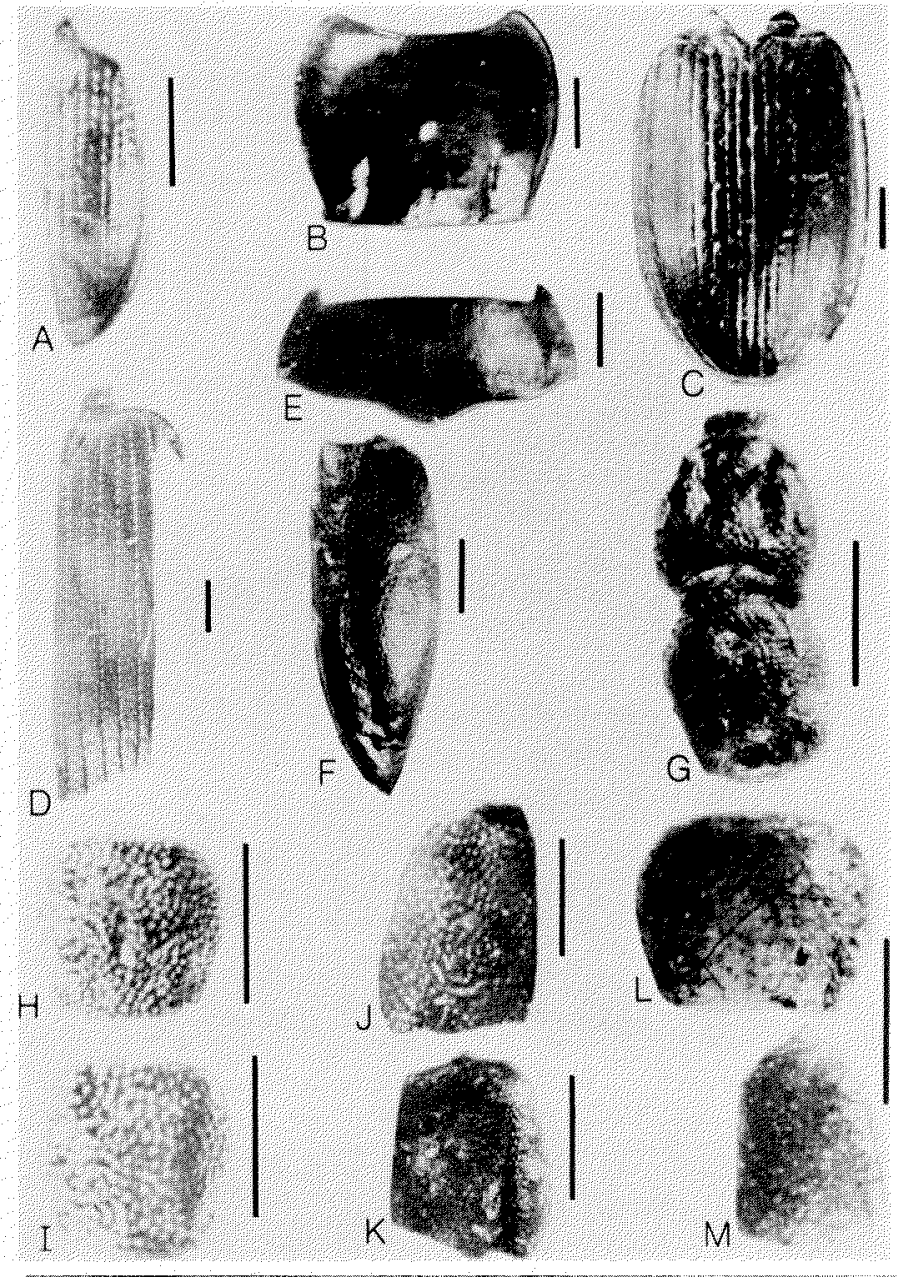

FIG. 3. Fossil beetles recovered from the two sites. A. Right elytron of Dyschirius sp. B. Pronotum of Pterostichus (Cryobius) nivalis. C. Fused elytra of Pterostichus (Cryobius) sp. D. Right elytron of Cymindis unicolor. E. Pronotum of Hydroporus (notabilis-arcticus complex) sp. F. Left elytron of Hydroporus morio. G. Head and pronotum of Holoboreaphilus nordenskioeldi. H. Pronotum of Stenus hyperboreus. K. Right elytron of Gymnusa sp. L. Pronotum of Micralymma brevilingue. M. Right elytron of Micralymma brevilingue. Scale bar equals $0.5 \mathrm{~mm}$. 
Island section (Fig. 3E) belongs to this complex, which has a range extending to the arctic and boreal regions of the holarctic.

The fossil specimen of Ilybius has been tentatively identified as 1 . angustior, a holarctic species found among emergent vegetation at the edge of standing water. The species of Helophorus is most likely $H$. parasplendidus (Smetana, pers. comm. 1983), which has been recorded from a number of arctic localities in North America (Angus, 1970).

Including the tentatively identified Pterostichus (Cryobius) nivalis previously mentioned, only four specimens, representing four species, can be classified as preferring xeric-type environments. The carabid beetle, Notiophilus borealis, is a northern species characteristic of xeric areas with sparse vegetation. It is distributed today throughout much of northern Alaska and Canada (Lindroth, 1969). Cymindis unicolor is a North American species found in areas of dry tundra (Fig. 4B; Lindroth, 1969). The elytral specimen recovered from the sediments possesses an incomplete basal margin (Fig. 3D), which according to Lindroth (1969) makes it $C$. vaporariorum, a palearctic species. However, Matthews (pers. comm. 1983) suspects that the character is more variable in $C$. unicolor than
Lindroth (1969) indicates. Matthews (pers. comm. 1983) has collected a teneral specimen of another (undescribed) species of $C y m i n d i s$ similar to both $C$. vaporariorum and $C$. unicolor. The fossil may represent this undescribed species. The staphylinid, Micralymma brevilingue (Fig. 3L, M), was considered to have primarily a coastal distribution in Alaska (Matthews, 1975a). However, Nelson (1982) has collected $M$. brevilingue on damp flanks of high-centered polygons in the vicinity of Barrow. Nelson has also recovered specimens of this species from the 9700-year-old sediments at a site on the Ikpikpuk River, which is well inland. The occurrence of this species is consistent with well-drained, sandy sites (Nelson, 1982).

One of the fossil weevil specimens has been assigned to the genus Dorytomus. The other weevil fossils are similar to both Dorytomus and other genera (Matthews, pers. comm. 1983). The genus Dorytomus is known to feed on willow.

\section{Niguanak Uplands}

The species recovered from the Niguanak Uplands site are presented in Table 4, as well as information on the habitat requirements of the taxa.
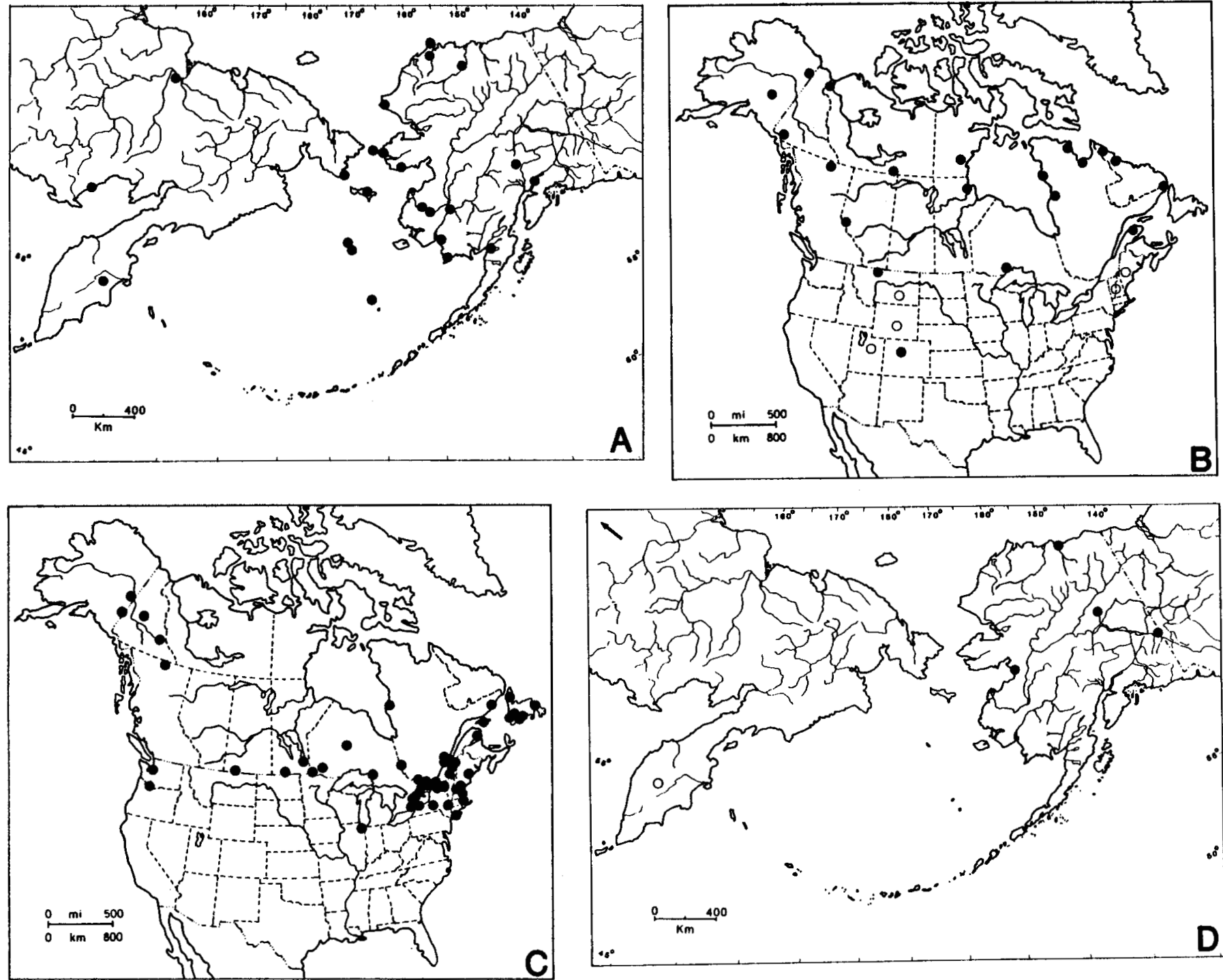

FIG. 4. Distribution maps of A. Pterostichus (Cryobius) nivalis (from Lindroth, 1966), B. Cymindis unicolor (from Lindroth, 1969), C. Tachyporus canadensis (from Campbell, 1979), and D. Stenus kamtschatichus (from Puthz, pers. comm. 1983). 
TABLE 4. Number of individuals recorded from the Niguanak Uplands section, showing habitat preferences

\begin{tabular}{|c|c|c|}
\hline Taxon & Minimum number of individuals & Habitat preference \\
\hline \multicolumn{3}{|l|}{ Class: INSECTA } \\
\hline \multicolumn{3}{|l|}{ Order: COLEOPTERA } \\
\hline \multicolumn{3}{|l|}{ Family: Carabidae } \\
\hline Dyschirius sp. & 10 & $\mathrm{M}, \mathrm{Sa}$ \\
\hline Pterostichus (Cryobius) sp. & 4 & \\
\hline Cymindis unicolor Kby. & 1 & $\mathrm{X},(\mathrm{T})$ \\
\hline Genus indet. & 5 & \\
\hline \multicolumn{3}{|l|}{ Family: Dytiscidae } \\
\hline Hydronorus sp. & 1 & A \\
\hline Agabus sp. & 1 & A \\
\hline Genus indet. & 2 & A \\
\hline \multicolumn{3}{|l|}{ Family: Hydrophilidae } \\
\hline Helophorus sp. & 1 & A \\
\hline \multicolumn{3}{|l|}{ Family: Staphylinidae } \\
\hline Olophrum sp. & 1 & $\mathbf{M}$ \\
\hline Holoboreaphilus nordenskioeldi (Mäkl.) & 4 & M,Arc, L \\
\hline Omaliinae indet. & 2 & \\
\hline Micralymma brevilingue Schiödt. & 1 & $\mathrm{X}, \mathrm{Arc}$ \\
\hline Stenus sp. & 7 & $\mathbf{M}$ \\
\hline Lathrobium sp. & 4 & \\
\hline Lordithon sp. & 1 & $\mathbf{M}$ \\
\hline Tachinus sp. & 1 & \\
\hline Tachyporus canadensis Campbl. & 1 & $\mathrm{M}, \mathrm{L}$ \\
\hline Tachyporus sp. & 1 & \\
\hline Gymnusa sp. & 1 & $\mathbf{M}$ \\
\hline Genus indet. & 6 & \\
\hline \multicolumn{3}{|l|}{ Family: Elateridae } \\
\hline Genus indet. & 1 & $\mathbf{M}$ \\
\hline \multicolumn{3}{|l|}{ Family: Curculionidae } \\
\hline Genus indet. & 4 & \\
\hline \multicolumn{3}{|l|}{ Order: DIPTERA } \\
\hline Genus indet. & 1 & \\
\hline \multicolumn{3}{|l|}{ Order: TRICHOPTERA } \\
\hline \multicolumn{3}{|l|}{ Family: Limnephilidae } \\
\hline Genus indet. & 1 & A \\
\hline \multicolumn{3}{|l|}{ Order: HEMIPTERA } \\
\hline Genus indet. & 1 & \\
\hline \multicolumn{3}{|l|}{ Class: ARACHNIDA } \\
\hline \multicolumn{3}{|l|}{ Order: ACARINA } \\
\hline \multicolumn{3}{|l|}{ Family: Orabatidae } \\
\hline Genus indet. & 16 & \\
\hline
\end{tabular}

\section{Key}

A Aquatic environment

Arc Arctic

EmV Emergent vegetation at edge of standing water

L Leaf litter

$\begin{array}{ll}\text { M } & \text { Mesic environment } \\ \text { SA } & \text { Sandy streamsides } \\ \text { (T) } & \text { Predominantly on tundra but not obligatory } \\ \text { X } & \text { Xeric environment }\end{array}$

Again, the small sample sizes and low concentration of beetles has resulted in the recovery of only 79 insect and arachnid fossils from the entire section. The 79 individuals comprise 26 taxa (including specimens only identified to family level). Twelve of these taxa were identified only to genus level and only four species were identified. Of the 79 individuals $76 \%$ belong to the order Coleoptra, $20 \%$ are Oribatidae (class Arachnida), and the other $4 \%$ are from the orders Diptera, Trichoptera and Hemiptera.

The percentages of individuals from the whole section associated with aquatic, mesic and xeric habitats are illustrated in Figure 2B. Fifty-six percent of the individuals present are taxa characteristic of mesic habitats. Those taxa that are riparian, including Dyschirius (Fig. 3A) and Gymnusa (Fig. 3K), are also included in this group. Only $7.5 \%$ of the species are characteristic of aquatic habitats and $2.5 \%$ are characteristic of xeric habitats. Twenty-five percent of the individuals could not be classified into a substrate moisture preference category.

The carabid genus Dyschirius is often found on sandy banks of streams, rivers and ponds. It feeds almost exclusively on the staphylinid beetle Bledius, which burrows into moist sand or mud along shores of oceans, lakes, rivers, streams or in salt flats or temporarily moist soil. Bledius feed on algae and diatoms (White, 1983). Other taxa found in mesic environments include Pterostichus (Cryobius) sp. (Fig. 3C), Olophrum, Holoboreaphilus nordenskioeldi, Stenus, Lordithon, Tachinus, Tachyporus canadensis and Gymnusa. Gymnusa is a genus characteristic of boggy environments near open water. The adults and larvae of species of Lordithon are often associated with mushrooms, although adults are occasionally found in leaf litter or moss where mushrooms are absent. Adults of Lordithon are active predators of Diptera larvae (Campbell, 1982). Tachyporus canadensis is usually found in litter of vegetation in mesic habitats or in the nests of small mammals. Modern specimens have not as yet been found in northern Alaska (Fig. 4C; Campbell, 1979). Holoboreaphilus nordenskioeldi, Olophrum and Stenus are all characteristic of moist or riparian northern tundra environments.

The aquatic insect species recovered from the sediments are, in general, found in slow-flowing or standing water. 
Micralymma brevilingue and Cymindis cf. unicolor are the only species represented characteristic of xeric environments. The $C$. cf. unicolor possibly belongs to the "undescribed" species mentioned previously.

All the species recovered from the Niguanak Uplands site are characteristic of tundra environments today.

\section{PALEOENVIRONMENTAL INTERPRETATIONS}

The predominance of aquatic beetles in the fossil beetle assemblage from the $8000-7000$ B.P. sediments at Barter Island site, the laminated appearance of the deposit and the detrital nature of the organic sediment suggest that the sediments were deposited in a shallow lake or thaw lake environment. The habitat requirements of the mesic adapted beetles suggests that the vegetation surrounding the lake was probably damp sedge marsh, similar to that of thaw lake edges in the region today. The occurrence of Dorytomus fossils implies the presence of willow in the vegetation.

Undoubtedly, the local beetle fauna of the shallow lake is overrepresented. A few xeric beetles and the occurrence of sand layers in the deposit imply that some xeric situations were probably in the vicinity, although the number of beetles preferring xeric environments is very low.

The paleoenvironmental data from the Niguanak Uplands site from 10400 B.P. until 1320 B.P. suggest that the section may have been associated with a mesic vegetation growing along a sandy stream bank during that interval.

With the exception of the fossil Tachyporus canadensis from 6000 B.P. sediments at the Niguanak Uplands site, the fossil insects recovered from both of the sections are characteristic of the northern Alaskan tundra today. The presence of Tachyporus canadensis beyond its present limit may suggest a warmer climate than today. However, the recovery of a single specimen is not convincing evidence, and as yet little other evidence from either beetle, pollen or macrofossil records support a warm climatic episode for this time interval. The thermophilous beetle assemblages recorded by Nelson (1982) from the 9700 B.P. sediments at Ikpikpuk River and by Matthews (1975a) from 10900 B.P. deposits at Clarence Lagoon suggest a climatic amelioration at these times. However, the fossil beetle assemblages recovered from samples of similar age from these sections do not provide any evidence for a climate significantly different from that of today. Few fossils have been recovered thus far and the regional significance of the paleoenvironmental information from the assemblages is unknown.

Wilson (1984) suggests an increase of mean July temperatures of $2-3^{\circ} \mathrm{C}$, corresponding to a Betula (birch) pollen peak between 10400 and 800 B.P. The spread of birch is documented in many regions of Alaska during this period. Ager (1982) correlates Betula pollen zone assemblages with a shift to less continental climate in western Alaska between about 14000 and 6000-7000 B.P. Guthrie (1982) proposes a link between the large-scale extinctions of Beringian megafauna and changes in climate during this interval. He stresses changes in the seasonal distribution of moisture, winds and temperature between 14000 and 10000 B.P. as having resulted in increased zonation of vegetation, wet swampy ground and deep winter snows, resulting in a marked decrease of food for ungulates.

\section{ZOOGEOGRAPHIC IMPLICATIONS}

Danks(1981) notes that the Beringian insect fauna "emerged" from refugia following the final retreat of Wisconsin glacial ice. On the arctic coastal plain, rapid climatic amelioration commenced before 13500 B.P., the time of first establishment of balsam poplar in this region (Hopkins et al., 1981). Of the beetle species represented in the Barter Island and Niguanak fossil assemblages, several have been found in late Pleistocene age deposits from eastern Beringia. The ground beetles Notiophilus borealis and Pterostichus nivalis have been found in Wisconsin and Pre-Wisconsin age sediments at Cape Deceit (Matthews, 1974) and Eva Creek, Alaska (Matthews, 1968). Pterostichus nivalis has also been found in Mid-Wisconsin age deposits at Igushik, southwestern Alaska (Elias, unpubl. data) and in similar age deposits from the Porcupine River, Yukon Territory (Matthews, 1975b). The staphylinid beetles Holoboreaphilus nordenskioeldi and Stenus kamtschaticus have also been identified from Mid-Wisconsin age deposits along the Nuyukuk River, southwestern Alaska (Elias, unpubl. data). Morgan et al. (1984) have discussed possible refugia and post-glacial migration routes for Holoboreaphilus nordenskioeldi. It appears likely that most if not all of the Barter Island and Niguanak fossil insect taxa were a part of the Beringian insect fauna of the last glacial interval, and yet over half of the identified species from these assemblages currently have holarctic distributions. Only two of the species from the fossil lists are presently restricted to Alaska, the eastern Yukon Territory and eastern Siberia (amphiberingian distribution pattern, as described by Danks, 1981). These are Pterostichus nivalis (Fig. 4A) and Stenus kamtschaticus (Fig. 4D). While the Quaternary insect fossil record of central and eastern Canada is poorly known at best, it would appear likely that many of the species preserved in the Niguanak and Barter Island deposits survived at least the Wisconsin glaciation in Beringia and spread to the east following deglaciation.

\section{FUTURE INVESTIGATIONS}

There is an obvious need for additional investigations of late Pleistocene and Holocene fossil materials on the arctic coastal plain, as well as elsewhere in arctic North America, in order to delineate patterns of climatic and biotic change. Data on past and present insect distribution are meager, due to the patchy distribution of modern collecting and the paucity of studied fossil sites. Whenever possible, interdisciplinary studies should be performed, combining information from pollen, plant macrofossils, insects, other arthropod and vertebrate fossils. Logistical problems in the Arctic make it necessary that the broadest variety of modern and fossil sampling be done at every opportunity.

\section{ACKNOWLEDGEMENTS}

Funding for this research has been provided by the Arctic Institute of North America, the Explorers Club, the American Alpine Club, Sigma $\mathrm{Xi}$ and the Geological Society of America. Support for the final preparation of the manuscript was provided by a grant to Elias from the National Science Foundation, DPP 8314957. The authors would like to thank Drs. D.J. Larson, J.V. Matthews, Jr., V. Puthz, and A. Smetana for their help in identification of the insect fossils. 


\section{REFERENCES}

AGER, T.A. 1982. Vegetational history of western Alaska during the Wisconsin glacial interval and the Holocene. In: Hopkins, D.M., Matthews, J.V., Schweger, C.E., and Young, S.B., eds. Paleoecology of Beringia. New York: Academic Press. 75-94.

ANGUS, R.B. 1970. Revision studies of east palearctic and some neararctic species of Helophorus F. (Coleoptera; Hydrophilidae). Acta Zoologica Academiae Scientiarum Hungaricae 16:249-290.

1973. Pleistocene Helophorus (Coleoptera: Hydrophilidae) from Borislav and Starunialin in the westem Ukraine, with a reinterpretation of $M$. Lomnicki's species and a comparison with British Weichselian faunas. Philosophical Transactions of the Royal Society of London, Series B, 265:299-326.

BALL, G.E. 1966. A revision of the North American species of the subgenus Cryobius Chaudoir (Pterostichus, Carabidae, Coleoptera). Opuscula Entomologica Supplementum 28. 166 p.

CAMPBELL, J.M. 1978. A revision of the North American Omaliinae (Coleoptera: Staphylinidae). 1. The General Haida Keen, Pseudohaida Hatch, and Eudectoides New Genus. 2. The Tribe Coryphiini. Memoirs of the Entomological Society of Canada, No. $106.87 \mathrm{p}$.

1979. A revision of the genus Tachyporus Gravenhorst (Coleoptera: Staphylinidae) of North and Central America. Memoirs of the Entomological Society of Canada, No. 109. 95 p.

1982. A revision of the genus Lordithon Thompson of North and Central America (Coleoptera: Staphylinidae). Memoirs of the Entomological Society of Canada, No. $119.116 \mathrm{p}$.

COOPE, G.R. 1959. A Late Pleistocene insect fauna from Chelford, Cheshire. Proceedings of the Royal Society, B151:70-86.

1968. An insect fauna from Mid-Weichselian deposits at Brandon, Warwickshire. Philosophical Transactions of the Royal Society of London, Series B, 254:425-456.

1977. Fossil coleopteran assemblages as sensitive indicators of climatic changes during the Devensian (Last) cold stage. Philosophical Transactions of the Royal Society of London, Series B, 280:313-340.

1978. Constancy of insect species versus inconstancy of Quaternary environments. In: Mound, L.A., and Waloff, N., eds. Diversity of Insect Faunas. Royal Entomological Society of London Symposium 9:176-187.

DANKS, H.V., ed. 1981. Arctic Arthropods. A review of systematics and ecology with particular reference to the North American fauna. Ottawa: Entomological Society of Canada. $608 \mathrm{p}$.

ELIAS, S.A. 1985. Paleoenvironmental interpretations of Holocene insect fossil assemblages from four high-altitude sites in the Front Range, Colorado, U.S.A. Arctic and Alpine Research 17:31-48.

and WILKINSON, B. 1983. Lateglacial insect fossil assemblages from Logsigensee (Swiss Plateau). Studies in the Late Quaternary of Lobsigensee 3. Revue de Paléobiologie 2:189-204.

FALL, H.C. 1923. A revision of the North American species of Hydroporus and Agaporus. Privately printed. $129 \mathrm{p}$.

GUTHRIE, R.D. 1982. Mammals of the Mammoth Steppe as paleoenviron- mental indicators. In: Hopkins, D.M., Matthews, J.V., Schweger, C.E., and Young, S.B., eds. Paleoecology of Beringia. New York: Academic Press. 307-328.

HOPKINS, D.M., SMITH, P.A., and MATTHEWS, J.V. 1981. Dated wood from Alaska and the Yukon: implications for forest refugia in Beringia. Quaternary Research 15:217-249.

LARSON, D.J. 1975. The predaceous water beetles (Coleoptera: Dytiscidae) of Alberta: systematics, natural history and distribution. Quaestiones Entomologicae 11:245-498.

LINDROTH, C.H. 1948. Interglacial insect remains from Sweden. Sveriges Geologiska Undersoekning Serie C, 492 (Årsbok 42).

1966. The ground-beetles of Canada and Alaska, Part 4. Opuscula Entomologica, Supplementum 29:409-648.

1969. The Ground-Beetles of Canada and Alaska, part 6. Opuscula Entomologica Supplementum 34:945-1192.

LOMNICKI, A.M. 1894. Pleistocene owady z Boryslawia (Fauna Pleistocenica Insectorum Boryslavenium). Wydaw Muzy Dzieduszyck 4:3-116.

MATTHEWS, J.V. 1968. A paleoenvironmental analysis of three Late Pleistocene coleopterous assemblages from Fairbanks, Alaska. Quaestiones Entomologicae 4:202-224.

1974. Quaternary environments at Cape Deceit (Seward Peninsula, Alaska): evolution of a tundra ecosystem. Geological Society of America Bulletin 85:1353-1384.

1975a. Incongruence of macrofossil and pollen evidence: A case from the Late Pleistocene of the northern Yukon Coast. Geological Survey of Canada Paper 75-1, Part B:139-146.

1975b. Insects and plant macrofossils from two Quaternary exposures in the Old Crow-Porcupine region, Yukon Territory, Canada. Arctic and Alpine Research 7:249-260.

1976. Evolution of the subgenus Cyphelophorus (Genus Helophorus, Hydrophilidae): description of two new fossil species and discussion of Helophorus tuberculatus. Canadian Journal of Zoology 54:653-673.

MJÖBERG, E. 1916. Über die Insektenreste der sog. "Harnogytjja" im nordlichen Schweden. Sveriges Geologiska Undersoekning Serie C, 268 (Årsbok 9).

MORGAN, A.V., MORGAN, A., and MILLER, R.F. 1984. Range extension and fossil occurrences of Holoboreaphilus nordenskioeldi (Mäklin) (Coleoptera: Staphylinidae) in North America. Canadian Journal of Zoology 62:463-467.

NELSON, R.E. 1982. Late Quaternary environments of the western Arctic Slope, Alaska. Ph.D. thesis, Multidisciplinary Quaternary Paleoecology, University of Washington. $90 \mathrm{p}$.

SCHWERT, D.P. ANDERSON, T.W., MORGAN, A., MORGAN, A.V., and KARROW, P.F. 1985. Changes in Late Quaternary vegetation and insect communities in southwestern Ontario. Quaternary Research 23:205-226.

WHITE, R.E. 1983. A Field Guide to the Beetles of North America. Boston: Houghton Mifflin Company. 368 p.

WILSON, M.J. 1984. Modern and Holocene environments of the North Slope of Alaska. M.A. thesis, Institute of Arctic and Alpine Research, University of Colorado, Boulder. 253 p. 